\title{
CHEMICAL AGENTS AND SHADING LEVELS FOR THE PRODUCTION OF PEPPER SEEDLINGS
}

\author{
Eliana D. C. Binotti ${ }^{*}$, Edilson Costa ${ }^{2}$, Flávio F. da S. Binotti², Thiago B. Batista ${ }^{3}$ \\ ${ }^{1 *}$ Corresponding author. Universidade Estadual de Mato Grosso do Sul/ Cassilândia - MS, Brasil. E-mail: dclia78@yahoo.com.br
}

\section{KEYWORDS}

auxin, Capsicum

frutensens $\mathrm{L}$, gibberellin, light, nitrogen, paclobutrazol.

\begin{abstract}
The aim of this study was to evaluate protected cultivation environments with different levels of shading and application of foliar chemical agents, on growth, photosynthetic pigments and seedling quality of Capsicum frutensens $\mathrm{L}$. The experiment was developed at the State University of Mato Grosso do Sul, University Unit of Cassilândia, with chili pepper. Three cultivation environments (screen of 18,35 and 50\% of shading) and six leaf chemical agents were used [(1) control - without application; (2) Nitrogen (N) 1\%; (3) Paclobutrazol $50 \mathrm{mg} \mathrm{L}^{-1}+\mathrm{N} 1 \%$; (4) Auxin $0.05 \mathrm{~g} \mathrm{~L}^{-1}+\mathrm{N} 1 \%$; (5) Gibberellin $0.05 \mathrm{~g} \mathrm{~L}^{-1}$ $+\mathrm{N} 1 \%$; and (6) Auxin $0.05 \mathrm{~g} \mathrm{~L}^{-1}+$ Gibberellin $0.05 \mathrm{~g} \mathrm{~L}^{-1}+\mathrm{N} \mathrm{1 \%}$. Each environment was considered an experiment in which the completely randomized design was adopted and, afterwards, a joint analysis of the same was carried out. The growth and the biometric relations were evaluated. The leaf nitrogen application positively influences the growth and chlorophyll content of pepper seedlings; the application of nitrogen + growth regulator via foliar produces seedlings with higher growth and biometric relations in environments with $50 \%$ shading. For the production of seedlings with desirable morphological and physiological aspects, it is recommended to use a foliar application of paclobutrazol + nitrogen in an environment with $50 \%$ shading.
\end{abstract}

\section{INTRODUCTION}

The pepper (Capsicum spp.) has been gaining space in the national and international markets and the increase in consumption by the world population has stimulated the commercialization of this vegetable and the exploration of new varieties. The different forms of value aggregation have also contributed to the increase of researches with the crop, in order to have an economic gain and overcoming morphological problems still found when working with the crop. Therefore, the most important step in the formation of a seedling with quality reflects on its productive system, the initial planning is essential to reach a better and more competitive market.

The formation of pepper seedlings is one of the most important phases of their production and one must take into account the morphological and physiological parameters to obtain healthy and vigorous raw materials. Investments have been made in research about quality using alternative products, but there are still few studies to verify their performance in the growth physiology and development of the seedlings. However, the use of growth inhibitors can enable the production of lower and more compact seedlings, besides stimulating the metabolism and the development of other morpho-physiological structures in the plant.

The Paclobutrazol is a growth regulator that inhibits the synthesis of gibberellins, producing a decrease in vegetative growth decreasing the cell elongation. The commercial products with this active ingredient are widely used in the flower market, in order to obtain small plants. These changes may also be of interest to seedlings producers, since smaller plants can facilitate transport and cultural practices.

The plant hormones, such as auxin and gibberellin, and the mineral nutrients, such as nitrogen, are important for the physiological and biochemical processes that occur in seeds and plants, and the responses from these metabolisms are necessary throughout their life cycle, contributing to the linear increase in crop productivity.

The light is the primary source of energy that drives the photosynthesis process in plants, but the amount and the quality of light will influence the energy generated to boost their metabolism, for example, the chlorophyll synthesis. In order to obtain a quality plant, it is important to distribute the luminosity index throughout its cycle,

${ }^{2}$ Universidade Estadual de Mato Grosso do Sul/ Cassilândia - MS, Brasil.

${ }^{3}$ Universidade Estadual Paulista "Júlio de Mesquita Filho"/ Botucatu - SP, Brasil.

Received in: 5-4-2016

Accepted in: 6-12-2018 
including its initial phase, as in the production of seedlings.

The production of seedlings in protected nurseries has advantages over open field cultivation, as it allows the plant protection against climatic adversities and the increase of efficiency in the use of water and fertilizers. The plant ambience also aims to identify the best climatic conditions in the production area and to obtain better seedlings, yields and productivity (Oliveira et al., 2012), as well as to significantly influence the development, allowing a greater uniformity and ripening in the field (Costa et al., 2015). The raw materials most commonly used for the production of seedlings in protected cultivation are polyethylene plastics and shading screens (Lima et al., 2016).

The seedlings production involves a series of practices and care to obtain quality vegetative material before final planting, that is, for the producer or nursery owner, fast and practical methods for verifying quality seedlings can be tested through evaluations of the morphological or physiological parameters, which may help to understand the requirements of these seedlings in the field. For the formation of pepper seedlings, different types of shaded nurseries have been used to ensure good development and gain in productivity. Therefore, the aim was to evaluate protected cultivation environments with different levels of shading and application of foliar chemical agents, on growth, photosynthetic pigments and seedling quality of Capsicum frutensens $\mathrm{L}$.

\section{MATERIAL AND METHODS}

The experiment was conducted in different growing environments, from November 2014 to February 2015, at the State University of Mato Grosso do Sul, University Unit of Cassilândia (516 m, 51 $1^{\circ} 44^{\prime} 03^{\prime \prime} \mathrm{O}$ and $19^{\circ} 06^{\prime} 48^{\prime \prime}$
S, automatic station of CASSILANDIA-A742). The climate of the region is, according to the Köppen classification, tropical with dry season.

Three cultivation environments were evaluated: (A1) and (A2) were nurseries with screen, structure in eucalyptus and measures of $5.0 \times 5.0 \times 2.5$ m (length $\mathrm{x}$ width $\mathrm{x}$ height), with cover and lateral shading screen, with meshes of 18 and $35 \%$ of transmissivity (Sombrite ${ }^{\circledR}$ ), respectively; (A3) was characterized as a nursery with screen, measures of $8.00 \mathrm{~m} \times 18.00 \mathrm{~m} \times 3.50 \mathrm{~m}$ (length $\mathrm{x}$ width $\mathrm{x}$ height), of galvanized steel structure, with cover and side of shading screen, with mesh $50 \%$ of transmissivity (Sombrite ${ }^{\circledR}$ ).

Data from photosynthesis active radiation (PAR) and temperature were collected. The PAR was collected with the help of a portable pyramidometer MP-200 (Pyranometer Separate Sensor with Handheld Meter), Apogee brand, at 8:40 a.m. The temperature was collected using a portable digital Thermo-hygrometer, in two schedules, at 8:40 a.m. and at 3:00 p.m., obtaining a daily average.

Within the 18, 35 and 50\% shading environments, we observed a PAR of $1295 \mu \mathrm{mol} \mathrm{m} \mathrm{m}^{-2} \mathrm{~s}^{-1}, 748 \mu \mathrm{mol} \mathrm{m} \mathrm{m}^{-2} \mathrm{~s}^{-1}$ and $548 \mu \mathrm{mol} \mathrm{m} \mathrm{m}^{-2} \mathrm{~s}^{-1}$, respectively. The PAR outside the growing environment was $1872 \mu \mathrm{mol} \mathrm{m} \mathrm{m}^{-2} \mathrm{~s}^{-1}$, with the temperature in the three environments remaining around $26^{\circ} \mathrm{C}$.

The seeds of chili pepper (Capsicum frutensens $\mathrm{L}$ ) were obtained without previous treatment and had their initial physiological quality determined in the seed analysis laboratory of this university, following the methodology contained in the seed analysis rule (Brasil, 2009). The results were described in Table 1.

TABLE 1. Initial physiological quality of the seeds. Cassilândia - MS, 2014.

\begin{tabular}{|c|c|c|c|c|}
\hline \multirow{2}{*}{ Seeds quality } & \multicolumn{2}{|c|}{---Germination (\%)--- } & \multirow{2}{*}{ IGS $^{*}$} & \multirow{2}{*}{ Electrical conductivity $\left(\mu \mathrm{S} \mathrm{cm}^{-1} \mathrm{~g}^{-1}\right)$} \\
\hline & $1^{\text {st }}$ count & Total & & \\
\hline Batch & 49 & 92 & 6.41 & 37.75 \\
\hline
\end{tabular}

*Index of germination speed.

For the seedlings production, expanded polystyrene trays with 128 cells (volume of $50 \mathrm{~mL}$ each cell) filled with Bioplant ${ }^{\circledR}$ commercial substrate were seeded with one seed per cell. The daily irrigation was carried out through a hand irrigator, according to the need of the crop.

The foliar application of the products was carried out at 21 days after sowing ( $100 \mathrm{~mL}$ of product per tray) at 8:00 a.m. Nitrogen in the form of urea, auxin in the form of indolebutyric acid and gibberellin in the form of gibberellic acid $\left(\mathrm{GA}_{3}\right)$ were used to prepare the products.

After 14 days of the products application, the following evaluations were carried out: (1) stem diameter, (2) plant height, (3) relation of plant height and stem diameter, (4) phytomass of dry material of shoot part, root and total, (5) relation of dry phytomasses of shoot part and root (6) Chlorophyll a, b and total (7) relation between chlorophyll a and chlorophyll b and (8) Dickson quality index (Dickson et al., 1960).

The stem diameter was measured to one centimeter of the ground using a digital caliper; and the plant height, a graduated ruler. In order to obtain the dried phytomasses of the shoot part and root, they were taken to the forced circulation air oven at a temperature of $65^{\circ} \mathrm{C}$ for 72 hours and, for the total dried phytomass, the sum of the dry phytomasses shoots and roots was done. We determined the chlorophylls using $0.5 \mathrm{~g}$ of leaf tissue and they were macerated in $10 \mathrm{~mL}$ of acetone; the extract was then centrifuged at $1500 \mathrm{rpm}$ for $10 \mathrm{~min}$ and the wavelength readings were taken at 645 and $663 \mathrm{~nm}$; then these readings were used in the equations for quantifications of Chlorophyll A $\left(\mathrm{mg} \mathrm{L}^{-1}\right)=12.7$ x DO663 - 2.69 x DO645; Chlorophyll B $\left(\mathrm{mg} \mathrm{L}^{-1}\right)=22.9 \times$ DO645 - $4.69 \times$ DO663; total chlorophyll $(\mathrm{a}+\mathrm{b})\left(\mathrm{mg} \mathrm{L}^{-1}\right)=20.2 \times \mathrm{DO} 645+8.02 \mathrm{x}$ D0663.

Because there were no replications of the growing environments, each was considered an experiment. For each cultivation environment (shading screen of 18, 35 and $50 \%$ of shading), a completely randomized experimental design was used to evaluate the leaf chemical agents [(1) control - without application; (2) Nitrogen (N) 1\%; (3) Paclobutrazol $50 \mathrm{mg} \mathrm{L}^{-1}+\mathrm{N} 1 \%$; (4) Auxin $0.05 \mathrm{~g} \mathrm{~L}^{-1}+\mathrm{N}$ $1 \%$; (5) Gibberellin $0.05 \mathrm{~g} \mathrm{~L}^{-1}+\mathrm{N} 1 \%$; and (6) Auxin 0.05 
$\mathrm{g} \mathrm{L}^{-1}+$ Gibberellin $0.05 \mathrm{~g} \mathrm{~L}^{-1}+\mathrm{N} 1 \%$, with four replicates of sixteen seedlings each. The environments were evaluated by the experiment group analysis (Banzatto \& Kronka, 2013).

The data were submitted to analysis of variance $(\mathrm{F}$ test) and the averages were compared by the Tukey test at $5 \%$ probability for the chemical agents and by the $\mathrm{F}$ test itself for the cultivation environments. The chlorophyll a, $\mathrm{b}$, total and chlorophyll $\mathrm{a}$ and $\mathrm{b}$ variables were transformed according to $\log (x+100)$.

\section{RESULTS AND DISCUSSION}

In all growth and seedling quality variables (except leaf chlorophyll content), the treatments studied were significant at $1 \%$ probability level, with interactions between the factors studied in the evaluations performed (Table 2).
The largest stem diameter relative to the crop environment was verified in the $50 \%$ shading environment, when nitrogen $(\mathrm{N})$ was applied with the growth regulators (Table 3). The control or $\mathrm{N}$ application provided higher averages when in environments with lower level of shading (Table 3). This fact can be correlated with the height data of the plant shoot part, since in the control, at levels lower than $50 \%$ of shading it allowed the reach of higher averages. On the other hand, the plants that received exogenous application of phytogulators, the highest level of shading $(50 \%)$ in this variable provided plants with larger diameter and shoot length, except for the shoot length variable with nitrogen + paclobutrazol, evidencing that the response in relation to the shading level is modified with the use of solutions with plant regulators in its composition.

TABLE 2. F values calculated of the analysis of variance and significance levels. Cassilândia - MS, 2015.

\begin{tabular}{|c|c|c|c|c|}
\hline \multirow{3}{*}{${ }^{1} \mathrm{CV}$} & \multicolumn{4}{|c|}{ VARIABLES } \\
\hline & Stem diameter & Height & $H D R$ & \\
\hline & $(\mathbf{m m})$ & $(\mathbf{c m})$ & $\mathrm{cm} \mathrm{mm}^{-1}$ & $D Q I$ \\
\hline Environments (E) & $57.01^{* *}$ & $90.37^{* * *}$ & $37.23^{* *}$ & $46.80^{* *}$ \\
\hline Solutions (S) & $44.22^{* *}$ & $394.18^{* *}$ & $124.50^{* *}$ & $57.83^{* *}$ \\
\hline \multirow[t]{4}{*}{ ExS } & $17.21^{* *}$ & $31.21^{* *}$ & $3.98^{* *}$ & $26.14^{* *}$ \\
\hline & \multicolumn{3}{|c|}{ Dry phytomass } & Relation \\
\hline & $S P$ & Root & Total & DP SP/Root \\
\hline & 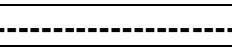 & nt --------------.. & ---------- & \\
\hline Environments (E) & $123.41^{* *}$ & $32.10^{* *}$ & $92.71^{* *}$ & $51.70^{* *}$ \\
\hline Solutions (S) & $106.73^{* *}$ & $55.85^{* *}$ & $89.63^{* *}$ & $76.51^{* *}$ \\
\hline \multirow[t]{2}{*}{ ExS } & $44.17^{* *}$ & $27.26^{* *}$ & $41.52^{* *}$ & $4.28^{* *}$ \\
\hline & Chlorophyll a & Chlorophyll b & Total Chlorophyll & $\mathbf{R} \mathbf{a} / \mathbf{b}$ \\
\hline \multicolumn{5}{|c|}{ - } \\
\hline$\overline{\text { Environments (E) }}$ & $0.11^{\mathrm{ns}}$ & $0.26^{\mathrm{ns}}$ & $0.22^{\mathrm{ns}}$ & $0.001^{\mathrm{ns}}$ \\
\hline Solutions (S) & $2.92^{*}$ & $7.26^{* *}$ & $5.38^{* *}$ & $0.46^{\mathrm{ns}}$ \\
\hline $\mathbf{E} \times \mathbf{S}$ & $0.06^{\mathrm{ns}}$ & $0.17^{\mathrm{ns}}$ & $0.11^{\mathrm{ns}}$ & $0.11^{\mathrm{ns}}$ \\
\hline
\end{tabular}

${ }^{1} \mathrm{CV}=$ cause of variation; HDR $=$ height and diameter ratio, $\mathrm{DQI}=$ Dickson index, $\mathrm{SP}=$ shoot part, $\mathrm{DP}=$ dry phytomass, $\mathrm{R}=$ relation. $* *=$ significant $1 \%$.

Santos et al. (2014), working with production of Ochroma lagopus Sw. seedlings with $30 \%$ and $50 \%$ shading screen, a $30 \%$ reflective thermo screen and a $50 \%$ reflective thermo screen and full sun, cites that the highest values found for the plant height were obtained in the environment with $50 \%$ reflective thermo. Santos et al. (2010), when working with eucalyptus seedlings and a $50 \%$ shading screen, observed that the eucalyptus seedlings arranged under shading presented higher growth averages in height and affirm that such differentiated behavior can be attributed to the greater competition for light and space, which brings the plant to the etiolation.

When evaluating foliar application in the different cultivation environments, in the 18 and $35 \%$ environments, the highest averages of the stem diameter are reached with the application of N. For the 50\% shading environment, the application of $\mathrm{N}+$ plant regulator provided higher values for this variable. The highest height of the plant shoot part occurred when $\mathrm{N}+$ gibberellin was applied at all levels of shading, and when comparing the products application via leaf, the lowest height of the plant shoot part occurred when $\mathrm{N}+$ paclobutrazol was applied
(Table 3 and Figure 1), because the gibberellin has a direct effect on the growth of the plant shoot part and the paclobutrazol by inhibiting the biosynthesis provides less growth of the plant.

In the relation between the height of the seedling and its stem diameter (HDR), there was no difference between the levels of shading in the control and when applying the nitrogen. In the application of $\mathrm{N}+$ paclobutrazol, higher averages were reached by subjecting the seedlings to a lower shading (15 and 35\%). In general, the other variables, a $35 \%$ shading environment provided higher averages for HDR (Table 3 ).

The dry phytomass of the plant shoot part (Table 4) was higher in the shade level of $50 \%$ when applied with the nitrogen + plant regulator via foliar (Figure 1). However, the control had no influence on the level of shading for this characteristic evaluated, in pepper plants, there is a differentiated response of the shading level using solutions with chemical agents via foliar $(\mathrm{N}+$ plant regulator), with greater accumulation of photoassimilates in the shoot part with lower solar incidence in the environment. 
TABLE 3. Results of significant interactions for the stem diameter $(\mathrm{mm})$, height $(\mathrm{cm})$, and relation between height and diameter (HDR) $\left(\mathrm{cm} \mathrm{mm}^{-1}\right)$ in function of three different cultivation environments and different chemical agents applied via foliar. Cassilândia - MS, 2015.

\begin{tabular}{|c|c|c|c|}
\hline \multirow{3}{*}{ Solutions } & \multicolumn{3}{|c|}{ Environment (\%) } \\
\hline & 18 & 35 & 50 \\
\hline & \multicolumn{3}{|c|}{ Stem diameter $(\mathrm{mm})$} \\
\hline Control & 0.733 a B & 0.725 a C & $0.633 \mathrm{~b} \mathrm{C}$ \\
\hline Nitrogen $(\mathbf{N})$ & $0.995 \mathrm{ab} A$ & $1.050 \mathrm{a} \mathrm{A}$ & $0.928 \mathrm{~b} \mathrm{~B}$ \\
\hline N + Paclobutrazol & 0.843 b B & $0.858 \mathrm{~b} \mathrm{~B}$ & $1.115 \mathrm{a} \mathrm{A}$ \\
\hline $\mathbf{N}+\operatorname{Auxin}(\mathbf{A})$ & $0.803 b \mathrm{~B}$ & $0.880 \mathrm{~b} \mathrm{~B}$ & $1.090 \mathrm{a} \mathrm{A}$ \\
\hline N + Gibberellin (G) & $0.823 \mathrm{~b} \mathrm{~B}$ & 0.730 c C & $1.043 \mathrm{a} \mathrm{A}$ \\
\hline$\underline{\mathbf{N}+\mathbf{A}+\mathbf{G}}$ & $0.768 \mathrm{~b} \mathrm{~B}$ & $0.733 \mathrm{~b} \mathrm{C}$ & $1.020 \mathrm{a} \mathrm{AB}$ \\
\hline \multirow[t]{2}{*}{ CV (\%) } & \multicolumn{3}{|c|}{6.12} \\
\hline & \multicolumn{3}{|c|}{ Height (cm) } \\
\hline Control & 2.97 a D & $3.00 \mathrm{a} \mathrm{E}$ & $2.64 \mathrm{~b} \mathrm{~F}$ \\
\hline Nitrogen $(\mathbf{N})$ & $4.35 \mathrm{~b} \mathrm{~B}$ & 5.05 a B & $4.00 \mathrm{c} \mathrm{D}$ \\
\hline N + Paclobutrazol & $3.13 \mathrm{~b} \mathrm{D}$ & 3.58 a D & $3.50 \mathrm{a} E$ \\
\hline $\mathbf{N}+\operatorname{Auxin}(\mathbf{A})$ & $3.61 \mathrm{c} \mathrm{C}$ & $4.59 \mathrm{~b} \mathrm{C}$ & 5.17 a $\mathrm{C}$ \\
\hline N + Gibberellin (G) & $5.19 \mathrm{c} \mathrm{A}$ & $5.51 \mathrm{~b} \mathrm{~A}$ & 6.17 a $\mathrm{A}$ \\
\hline$\underline{\mathbf{N}}+\mathbf{A}+\mathbf{G}$ & 4.10 c B & $4.74 \mathrm{~b} \mathrm{BC}$ & $5.62 \mathrm{a} \mathrm{B}$ \\
\hline \multirow[t]{2}{*}{ CV (\%) } & \multicolumn{3}{|c|}{4.05} \\
\hline & \multicolumn{3}{|c|}{ HDR } \\
\hline Control & 4.06 a CD & 4.15 a D & $4.20 \mathrm{a} \mathrm{B}$ \\
\hline Nitrogênio (N) & $4.41 \mathrm{a} C D$ & $4.81 \mathrm{a} C D$ & $4.32 \mathrm{a} B$ \\
\hline N + Paclobutrazol & 3.75 a D & 4.18 a D & $3.14 \mathrm{~b} \mathrm{C}$ \\
\hline $\mathbf{N}+\operatorname{Auxin}(\mathbf{A})$ & $4.50 \mathrm{~b} \mathrm{C}$ & 5.23 a C & $4.75 \mathrm{ab} B$ \\
\hline N + Gibberellin (G) & $6.31 \mathrm{~b} \mathrm{~A}$ & 7.56 a A & $5.92 \mathrm{~b} \mathrm{~A}$ \\
\hline$\underline{\mathbf{N}+\mathbf{A}+\mathbf{G}}$ & $5.33 \mathrm{~b} \mathrm{~B}$ & $6.52 \mathrm{a} \mathrm{B}$ & $5.52 \mathrm{~b} \mathrm{~A}$ \\
\hline CV (\%) & & 6.83 & \\
\hline
\end{tabular}

At the shade levels of 18 and $35 \%$, the nitrogen application provided higher dry phytomass of the plant shoot part, in the 50\% shading, larger averages were obtained with the application of nitrogen + phytoregulator, again being verified a distinct behavior in relation to the growth of the plant with interaction levels of shading and foliar application of the solutions, we can confirm in the results obtained that the nitrogen applied via foliar has a direct positive influence on the pepper plants, providing plants with greater phytomass regardless of the level of shading (Table 4).

The nitrogen is a nutrient required in large quantities by crops, as it induces rapid vegetative growth and directly influences production (Table 4). In the study conducted by Martuscello et al. (2015), there were data that corroborate with this research, since they mention that the increase of the production with the addition of the nitrogen is explained by the fact that $\mathrm{N}$ acts as a controlling factor of the different processes of growth and development of the plants, providing increase of biomass by carbon fixation.

The nitrogen application with paclobutrazol provided good results in relation to the root dry phytomass (table 4), in this treatment also obtained good results of stem diameter and HDR, resulting in more robust seedlings (Table 3), mainly in the environment with a $50 \%$ shading level, it provided a more adequate partition of photoassimilates to form high quality seedlings because they had a growth with a lower energy investment to increase the plants height that provided higher energy available for root system growth and stem diameter. 
TABLE 4. Results of significant interactions for the shoot dry phytomass $(\mathrm{g})$, root $(\mathrm{g})$, total (g) and shoot and root dry phytomass relation, according to three cultivation environments and different chemical agents applied via foliar. Cassilândia MS, 2015.

\begin{tabular}{|c|c|c|c|}
\hline \multirow{3}{*}{ Solutions } & \multicolumn{3}{|c|}{ Environment (\%) } \\
\hline & 18 & 35 & 50 \\
\hline & \multicolumn{3}{|c|}{ Shoot dry phytomass (g plant) } \\
\hline Control & 0.036 a D & 0.032 a D & 0.025 a D \\
\hline Nitrogen $(\mathbf{N})$ & $0.140 \mathrm{~b} \mathrm{~A}$ & 0.180 a $\mathrm{A}$ & 0.090 с C \\
\hline N + Paclobutrazol & 0.060 с C & $0.100 \mathrm{~b} \mathrm{BC}$ & 0.150 a B \\
\hline $\mathbf{N}+\operatorname{Auxin}(\mathbf{A})$ & $0.070 \mathrm{c} \mathrm{BC}$ & $0.130 \mathrm{~b} \mathrm{~B}$ & 0.180 a $\mathrm{A}$ \\
\hline N + Gibberellin $(\mathbf{G})$ & $0.100 \mathrm{~b} \mathrm{~B}$ & $0.090 \mathrm{~b} \mathrm{C}$ & 0.200 a $\mathrm{A}$ \\
\hline$\underline{\mathbf{N}+\mathbf{A}+\mathbf{G}}$ & $0.070 \mathrm{~b} \mathrm{BC}$ & $0.090 \mathrm{~b} \mathrm{C}$ & $0.200 \mathrm{a} \mathrm{A}$ \\
\hline \multirow[t]{2}{*}{ CV (\%) } & \multicolumn{3}{|c|}{12.25} \\
\hline & \multicolumn{3}{|c|}{ Root dry phytomass (g plant) } \\
\hline Control & 0.029 a C & $0.022 \mathrm{a} \mathrm{C}$ & 0.016 a B \\
\hline Nitrogen $(\mathbf{N})$ & $0.063 \mathrm{~b} \mathrm{~A}$ & 0.078 a $\mathrm{A}$ & 0.029 с B \\
\hline N + Paclobutrazol & 0.047 с $\mathrm{AB}$ & $0.071 \mathrm{~b} \mathrm{~A}$ & $0.093 \mathrm{aA}$ \\
\hline $\mathbf{N}+\operatorname{Auxin}(\mathbf{A})$ & $0.047 \mathrm{~b} \mathrm{AB}$ & 0.073 a $\mathrm{A}$ & 0.082 a A \\
\hline N + Gibberellin $(\mathbf{G})$ & $0.048 \mathrm{~b} \mathrm{AB}$ & $0.036 \mathrm{~b} \mathrm{BC}$ & 0.084 a A \\
\hline$\underline{\mathbf{N}+\mathbf{A}+\mathbf{G}}$ & $0.043 \mathrm{~b} \mathrm{BC}$ & $0.044 \mathrm{~b} \mathrm{~B}$ & $0.081 \mathrm{a} \mathrm{A}$ \\
\hline \multirow[t]{2}{*}{ CV (\%) } & & 14.46 & \\
\hline & \multicolumn{3}{|c|}{ Total dry phytomass (g plant) } \\
\hline Control & 0.065 a C & $0.054 \mathrm{a} \mathrm{E}$ & 0.041 a D \\
\hline Nitrogen $(\mathbf{N})$ & $0.205 \mathrm{~b} \mathrm{~A}$ & 0.256 a $\mathrm{A}$ & 0.119 с C \\
\hline N + Paclobutrazol & $0.111 \mathrm{c} \mathrm{B}$ & $0.173 \mathrm{~b} \mathrm{BC}$ & 0.240 a B \\
\hline $\mathbf{N}+\operatorname{Auxin}(\mathbf{A})$ & 0.118 с B & $0.201 \mathrm{~b} \mathrm{~B}$ & $0.262 \mathrm{a} \mathrm{AB}$ \\
\hline $\mathbf{N}+$ Gibberellin $(\mathbf{G})$ & $0.144 \mathrm{~b} \mathrm{~B}$ & $0.201 \mathrm{~b} \mathrm{D}$ & 0.262 a A \\
\hline$\underline{\mathbf{N}+\mathbf{A}+\mathbf{G}}$ & $0.117 \mathrm{~b} \mathrm{~B}$ & $0.137 \mathrm{~b} \mathrm{CD}$ & $0.281 \mathrm{a} \mathrm{AB}$ \\
\hline \multirow[t]{2}{*}{ CV (\%) } & \multicolumn{3}{|c|}{14.46} \\
\hline & \multicolumn{3}{|c|}{ Shoot dry phytomass and root relation } \\
\hline Control & $1.250 \mathrm{~b} \mathrm{D}$ & $1.430 \mathrm{ab} D$ & $1.570 \mathrm{a} \mathrm{C}$ \\
\hline Nitrogen $(\mathbf{N})$ & $2.280 \mathrm{~b} \mathrm{~A}$ & $2.300 \mathrm{~b} \mathrm{AB}$ & 3.140 a $\mathrm{A}$ \\
\hline N + Paclobutrazol & 1.360 a CD & 1.460 a D & 1.600 a C \\
\hline $\mathbf{N}+\operatorname{Auxin}(\mathbf{A})$ & $1.520 \mathrm{~b} \mathrm{CD}$ & $1.780 \mathrm{~b} \mathrm{CD}$ & $2.210 \mathrm{a} \mathrm{B}$ \\
\hline N + Gibberellin (G) & $2.010 \mathrm{~b} \mathrm{AB}$ & 2.580 a A & 2.420 a B \\
\hline$\underline{\mathbf{N}+\mathbf{A}+\mathbf{G}}$ & $1.740 \mathrm{c} \mathrm{BC}$ & $2.090 \mathrm{~b} \mathrm{BC}$ & $2.440 \mathrm{a} \mathrm{B}$ \\
\hline CV (\%) & & 14.46 & \\
\hline
\end{tabular}

${ }^{\mathrm{M}}$ Averages followed by different letters, lowercase in the lines and upper case in the column, within the environmental factors and solutions, differ statistically from each other by the Tukey test at $5 \%$ probability.

In the control, the shading level did not affect the root dry phytomass of the pepper plant, but with the application of nitrogen + plant regulator, the $50 \%$ shading allowed, in general, greater growth of the root system. The higher values of total dry phytomass of germinated seedlings were obtained in the treatments with nitrogen application + plant regulator when the seedlings are produced at the $50 \%$ shading level, following the same trend in relation to the phytomasses. In the treatment with the application of $\mathrm{N}+$ paclobutrazol, even having the smaller averages of shoot height, it obtained a total dry phytomass with good results, thus, a good incorporation of photoassimilates with a suitable partition, also, to obtain quality seedlings (stem diameter, HDR and dry root phytomass) and a good shoot dry phytomass and root relation (Table 4).

As previously evidenced, the treatment with $\mathrm{N}+$ paclobutrazol in a 50\% shading environment allowed a high Dickson quality index for pepper seedlings in comparison to other treatments used, not differing (Table 5 ), proving the results obtained previously in relation to the partition of photoassimilates suitable for the production of high quality pepper seedlings.

The leaf chlorophyll levels ( $a$ and $b$ ) were not influenced by shading levels, but the leaf chlorophyll a content in pepper plants submitted to $\mathrm{N}+$ Paclobutrazol and $\mathrm{N}+\mathrm{A}+\mathrm{G}$ presented higher averages values in relation to the control (Table 6 and figure 1). 
TABLE 5. Results of the significant interactions for Dickson quality index (DQI), in function of three cultivation environments and different chemical agents applied via foliar. Cassilândia - MS, 2015.

\begin{tabular}{|c|c|c|c|}
\hline \multirow{3}{*}{ Solutions } & \multicolumn{3}{|c|}{ Environment (\%) } \\
\hline & 18 & 35 & 50 \\
\hline & \multicolumn{3}{|c|}{ DQI } \\
\hline Control & $0.012 \mathrm{a} \mathrm{C}$ & $0.010 \mathrm{a} \mathrm{B}$ & 0.007 a D \\
\hline Nitrogen $(\mathbf{N})$ & $0.031 \mathrm{a} \mathrm{A}$ & 0.036 a A & $0.016 \mathrm{~b} \mathrm{C}$ \\
\hline $\mathbf{N}+$ Paclobutrazol & 0.022 c B & $0.031 \mathrm{~b} \mathrm{~A}$ & $0.051 \mathrm{a} \mathrm{A}$ \\
\hline $\mathbf{N}+\operatorname{Auxin}(\mathbf{A})$ & $0.020 \mathrm{c} \mathrm{BC}$ & $0.029 \mathrm{~b} \mathrm{~A}$ & 0.038 a B \\
\hline $\mathbf{N}+$ Gibberellin $(\mathbf{G})$ & $0.017 \mathrm{~b} \mathrm{BC}$ & $0.012 \mathrm{~b} \mathrm{~B}$ & $0.034 \mathrm{a} \mathrm{B}$ \\
\hline $\mathbf{N}+\mathbf{A}+\mathbf{G}$ & $0.017 \mathrm{~b} \mathrm{BC}$ & $0.016 \mathrm{~b} \mathrm{~B}$ & 0.035 a B \\
\hline $\mathrm{CV}(\%)$ & \multicolumn{3}{|c|}{14.46} \\
\hline
\end{tabular}

${ }^{\mathrm{M}}$ Averages followed by different letters, lowercase in the lines and upper case in the column, within the environmental factors and solutions, differ statistically from each other by the Tukey test at $5 \%$ probability.

For the chlorophyll $b$ and total, regardless of the product applied via foliar, there was an increase in the contents of the variables studied in relation to the control. In the relation between chlorophyll a and chlorophyll b, the treatments used did not influence this variable. The higher content of chlorophyll $\mathrm{b}$ in relation to $\mathrm{a}$, due to the protected culture environment, since the shading leads to a change in the chlorophyll balance in the vegetable, increase the chlorophyll $b$ content. Table 6 shows that the nitrogen has a direct influence on the chlorophyll biosynthesis by participating in its constitution, where the treatments that received the nitrogen supply via foliar obtained a minimum increase twice the total chlorophyll level, which had a reflection on the photosynthesis rate, thus in the vegetable growth (Table 3, 4 and 5).

TABLE 6. Averages of chlorophyll $a, b$, total and relation of chlorophyll $a$ and $b(a / b)$, in function of three cultivation environments and different chemical agents applied via foliar. Cassilândia - MS, 2015.

\begin{tabular}{|c|c|c|c|c|}
\hline \multirow{3}{*}{ Treatments } & \multicolumn{4}{|c|}{ Chlorophyll } \\
\hline & $\mathbf{a}$ & $\mathbf{b}$ & total & $\mathbf{a} / \mathbf{b}$ \\
\hline & \multicolumn{4}{|c|}{ 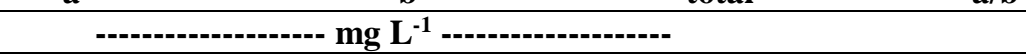 } \\
\hline \multicolumn{5}{|l|}{ Environment (\%) } \\
\hline$\overline{18}$ & 168.36 & 250.13 & 412.12 & 0.66 \\
\hline 35 & 150.35 & 227.57 & 368.47 & 0.64 \\
\hline 50 & 162.34 & 243.88 & 398.68 & 0.65 \\
\hline \multicolumn{5}{|l|}{ Solutions } \\
\hline Control & $58.26 \mathrm{~b}$ & $106.95 \mathrm{~b}$ & $164.98 \mathrm{~b}$ & 0.54 \\
\hline Nitrogen $(\mathrm{N})$ & $172.61 \mathrm{ab}$ & $263.25 \mathrm{a}$ & $432.64 \mathrm{a}$ & 0.65 \\
\hline $\mathrm{N}+$ Paclobutrazol & $212.30 \mathrm{a}$ & $307.40 \mathrm{a}$ & $512.45 \mathrm{a}$ & 0.68 \\
\hline $\mathrm{N}+\operatorname{Auxin}(\mathrm{A})$ & $160.27 \mathrm{ab}$ & $226.06 \mathrm{a}$ & $377.22 \mathrm{a}$ & 0.69 \\
\hline $\mathrm{N}+$ Gibberellin $(\mathrm{G})$ & $188.05 \mathrm{ab}$ & $277.26 \mathrm{a}$ & $463.17 \mathrm{a}$ & 0.68 \\
\hline $\mathrm{N}+\mathrm{A}+\mathrm{G}$ & $207.49 \mathrm{a}$ & $312.90 \mathrm{a}$ & $516.14 \mathrm{a}$ & 0.66 \\
\hline$\overline{C V(\%)}$ & 9.24 & 5.70 & 7.67 & 0.05 \\
\hline
\end{tabular}

${ }^{\mathrm{M}}$ Averages followed by different letters, lowercase in the column differ statistically from each other by the $\mathrm{F}$ test at $5 \%$ probability. 


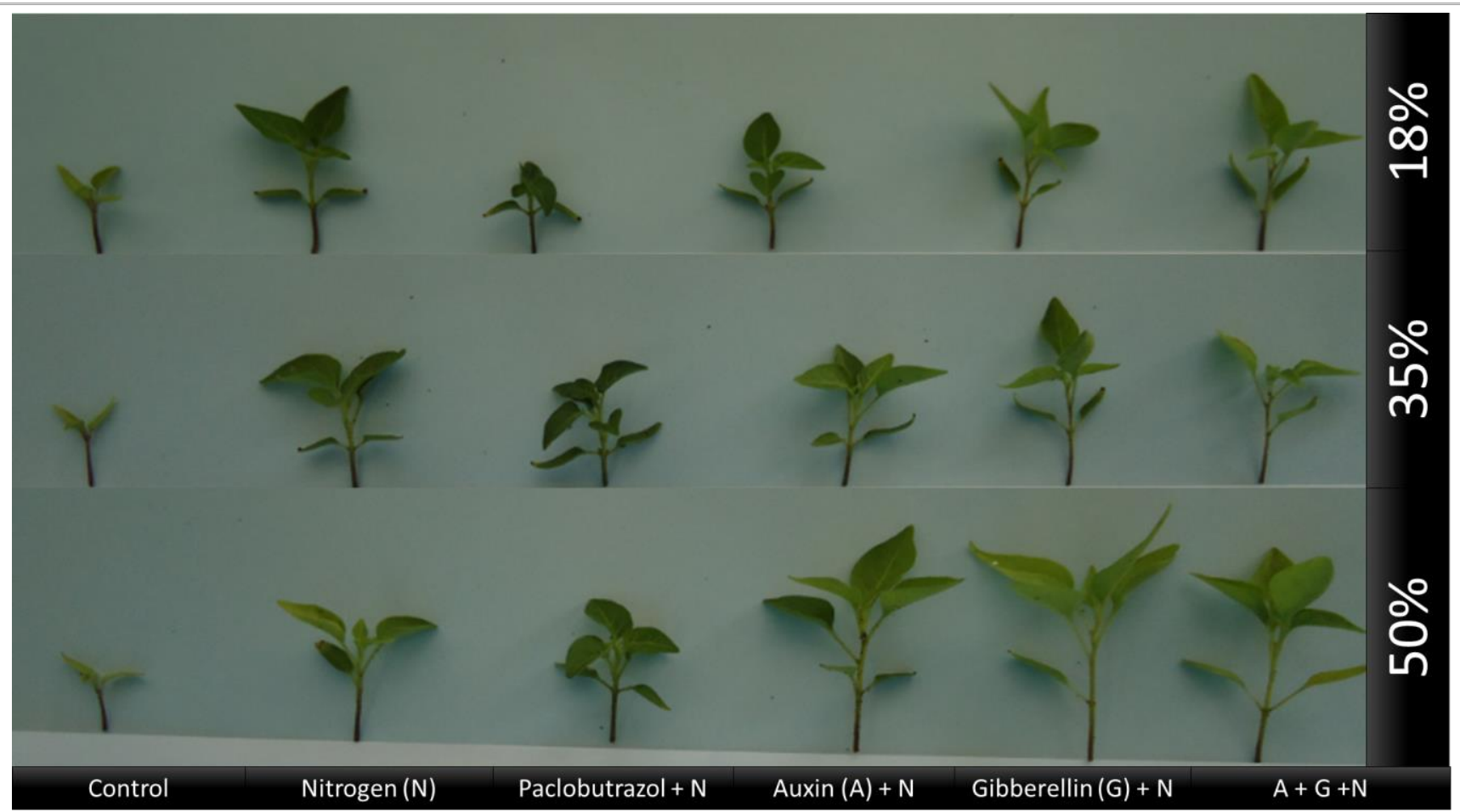

FIGURE 1. Pepper seedlings in formation subjected to different chemical agents' applications in the three growing environments. Cassilândia - MS, 2015.

\section{CONCLUSIONS}

The leaf nitrogen application positively influences the growth and chlorophyll content of pepper seedlings; the application of nitrogen + growth regulator via foliar produces seedlings with higher growth and biometric relations in environments with $50 \%$ shading.

For the production of seedlings with desirable morphological and physiological aspects, it is recommended to use a foliar application of paclobutrazol + nitrogen in an environment with 50\% shading.

\section{ACKNOWLEDGMENTS}

We would like to thank to PNPD/CAPES, Programa Nacional de Pós-Doutorado from CAPES for the scholarship. And to the CNPq for the scholarship. We thank to FUNDECT for the support to the research, Programa Primeiros Projetos PPP 05/2011, Proc. $\mathrm{N}^{\circ}$ 23/200.647/2012.

\section{REFERENCES}

Banzatto DA, Kronka SN (2013) Experimentação agrícola. Jaboticabal, Funep, 237 p.

Brasil (2009) Ministério da Agricultura, Pecuária e Abastecimento. Regras para análise de sementes. Brasília, Mapa/ACS, 399 p.

Costa E, Dias JG, Lopes KG, Binotti FFS, Cardoso ED (2015) Telas de Sombreamento e Substratos na Produção de Mudas de Dipteryx alata Vog. Floresta e Ambiente 22(3):416-425.
Dickson A, Leaf AL, Hosner JF (1960) Quality appraisal of white spruce and white pine seedling stock in nurseries. Forest Chronicle 36:10-13.

Lima IMO, Silva Júnior JS, Costa E, Cardoso ED, Binotti FFS, Jorge MHA (2016) Diferentes substratos e ambientes protegidos para o crescimento de mudas de maracujazeiro amarelo doce. Revista de Agricultura Neotropical 3(4):39-47.

Martuscello JA, Silva LP, Cunha DNFV, Batista ACS, Braz TGS, Ferreira PS (2015) Adubação nitrogenada em capim-massai: morfogênese e produção. Ciência Animal Brasileira 16(1):1-13.

Oliveira LC, Costa E, Cortelassi JAS, Rodrigues ET (2012) Formation of beetroot seedlings in different protected environments, substrates and containers in Aquidauana region, State of Mato Grosso do Sul, Brazil. Engenharia Agrícola 32(3):415-422.

Santos AF dos, Auer CG, Rodrigues LMR, Rodrigues Neto J (2010) Ocorrência de mancha foliar bacteriana em plantios de eucalipto no Estado de Mato Grosso e de Santa Catarina. Tropical Plant Pathology 35:232.

Santos UF, Ximenes FS, Luz PB, Seabra Júnior S, Paiva Sobrinho S (2014) Níveis de sombreamento na produção de mudas de pau-de-balsa (Ochroma pyramidale). Bioscience Jornal 30(1):129-136. 